\title{
EFFECTS OF ISOFLAVONES ON TESTICULAR WEIGHT AND TESTOSTERONE SECRETION IN ISA BROWN ROOSTERS*
}

\author{
Natasha Gjorgovska ${ }^{1 *}$, Kiril Filev ${ }^{2}$ \\ ${ }^{1}$ Institute of Animal Science, Ss. Cyril and Methodius University, \\ bul. Ilinden br. 92a, Skopje, Macedonia \\ ${ }^{2}$ Faculty of Agricultural Sciences and Food, Ss. Cyril and Methodius University, \\ bul. Aleksandar Makedonski bb, Skopje, Macedonia \\ •Corresponding author: natashagjorgovska@gmail.com
}

\begin{abstract}
Isoflavones are phytoestrogens which have estrogen-like activity in animals and humans. Because of this characteristic influence, the aim of this investigation was to examine the effect of genistein and daidzein on testicular weight and testosterone secretion in ISA Brown roosters. Genistein and daidzein as non-steroid phytoestrogens were added in large amounts to the feed of roosters. Soy isoflavones were added to rooster diets in amounts of $0,300,600,1200$ and $1800 \mathrm{mg} / \mathrm{kg}$ of feed. At the end of the 37th week no significant differences were found between the groups in testicular weight $(\mathrm{P}>0.05)$ and testosterone secretion $(\mathrm{P}>0.05)$ measured in the blood of birds. Blood testosterone concentration was significantly higher in younger (20-week-old) roosters than in 37-weekold roosters $(\mathrm{P}<0.01)$. Genistein and daidzein present in the feed did not influence the weight of testes and no significant differences were found. Further studies are required to investigate the effect of isoflavones on other androgenic characteristics.
\end{abstract}

Key words: roosters, isoflavones, testicles, testosterone

Genistein and daidzein are non-steroid phytoestrogens, from soybean products and other legumes which could be constituents of commercial poultry feed (Kurzer and $\mathrm{Xu}, 1997)$. They have estrogen-like biological activity and can influence animal and human reproduction by changing the sexual behaviour and morphology as well as the function of reproductive organs (Kurzer and Xu, 1997; Murkies et al., 1998). Genistein has been described as a specific inhibitor of tyrosine protein kinase (Akiyama et al., 1987). The effect of dietary phytoestrogen on avian reproduction was investigated. California quails fed a diet with a high concentration of these phytoestrogens had poor breeding success (Leopold et al., 1976). Several effects of genistein

\footnotetext{
*This work was supported by internal grant of Institute of Animal Science, No. 0201-317/08.
} 
on ovarian (Ciereszko et al., 2001, 2003; Makarevich et al., 1997; Whitehead and Lacey, 2000) and adrenal (Kamińska et al., 2002; Mesiano et al., 1999) steroidogenesis have been reported in mammals. There is no data concerning phytoestrogens and testicular steroidogenesis in domestic fowl. Therefore, the aim of this study was to investigate the effect of genistein and daidzein on blood testosterone concentration and testicular weight in mature roosters supplemented with large amounts of dietary phytoetrogens.

\section{Material and methods}

The experiment was performed in a commercial poultry farm. The animals were accommodated in cages during the period of rearing ( 7 chickens per cage) up to 20 weeks of age and after that 5 per cage until the end of the 37 th week of age. Fifty roosters, 20 weeks old, were divided into 5 groups (ten in each group, two cages per group) and fed different amounts of additional isoflavones. Group 0 was blank with no additional isoflavones in the feed and in the other 4 groups soy isoflavones were added in amounts of $0,300,600,1200$ and $1800 \mathrm{mg} / \mathrm{kg}$ of feed. The composition and nutritive value of the basal diet is presented in Table 1.

Table 1. Composition and nutritive value of the basal diet

\begin{tabular}{lc}
\hline \multicolumn{1}{c}{ Ingredients and analysis } & Percentage \\
\hline Yellow corn & 48.00 \\
Sunflower meal (40\% CP) & 43.24 \\
Fish meal & 0.42 \\
Soybean oil & 3.71 \\
L-lysine & 0.29 \\
Calcium carbonate & 1.66 \\
Monocalcium phosphate & 1.46 \\
Potassium carbonate & 0.22 \\
Minezyl (Zeolites) & 0.30 \\
Salt & 0.20 \\
Premix & 0.50 \\
Calculated analysis: & \\
$\quad$ dry matter (\%) & 90.98 \\
$\quad$ metabolizable energy (kcal/kg) & 2900 \\
$\quad$ crude protein (\%) & 21.80 \\
$\quad$ crude fat (\%) & 6.39 \\
$\quad$ crude fibre (\%) & 7.79 \\
total ash (\%) & 5.99 \\
Palcium (\%) & 1.05 \\
\hline
\end{tabular}


The roosters received additional isoflavones from 20 to 37 weeks of age. The body weight of the roosters was measured with a special digital balance at the beginning and at the end of the experiment. Blood samples at the 20th week were taken from 5 marked roosters, after the accommodation of 5 days, directly from the heart (cardiac puncture), and at the end of the 37 th week from the same animals.

Blood samples were centrifuged at $3500 \mathrm{rpm}$ for 15 minutes, not more than one hour after the cardiac puncture and the collected plasma was frozen at $-20^{\circ} \mathrm{C}$ in a freezer until analysis. A quantitative analysis of total serum testosterone was performed by ${ }^{125}$ I-based radioimmunoassay with the TESTO-RIA-CT Kit (IBL International GmbH, Hamburg, Germany) according to the instructions of the manufacturer. Sensitivity of the assay was $0.05 \mathrm{ng} / \mathrm{ml}$.

At the end of the experiment 5 roosters from each experimental group were sacrificed. The roosters were anaesthetized by inhalation with diethyl ether and killed. At necroscopy, the testes (right and left) were excised from the body and the weight was measured with a digital balance of $0.01 \mathrm{~g}$ accuracy.

Data were tested for significance using analysis of variance, F-test and T-test according to Snedecor and Cochran (1989).

\section{Results}

The results obtained are shown in Tables 2 and 3. The presented average body weight of the roosters (Table 2) indicates that birds from group 2 reached the highest body weight (1917 g) and those from group 1 the lowest (1648 g). These results were recorded at the end of the experiment when the roosters were 37 weeks old.

Testicular weight was measured at the same age. The weight of the left testis was $5.27 \mathrm{~g}$ and $5.33 \mathrm{~g}$ in groups 1 and 4, but in groups 0,2 and 3 the testes had higher weight $(6.59,6.72$ and 6.90 , respectively). The same trend was noticed for the right testis, the weight of which was $4.99 \mathrm{~g}$ and $6.62 \mathrm{~g}$ in groups 1 and 4, but 6.40, 5.72 and $6.62 \mathrm{~g}$ in groups 0,2 and 3, respectively. The total weight of the left and right testes in groups 1 and 4 was 10.24 and $10.34 \mathrm{~g}$, but in groups 0,2 and 3 it was higher at $12.99,12.44$ and $13.52 \mathrm{~g}$, respectively.

The relative weight of the measured testicles showed that in group 4 their weight was the lowest in relation to body weight. The highest relative weight was found in the control group and in group $3(0.70 \%$ and $0.72 \%$, respectively).

The highest blood concentration of testosterone in the roosters (Table 3) aged 20 weeks, after 5 days of the accommodation, was found in group $1(1298.33 \mathrm{pg} / \mathrm{ml})$, and the lowest in group $0(567.00 \mathrm{pg} / \mathrm{ml})$. This means that the additional amount of isoflavones in the feed influenced testosterone secretion. In the blood of roosters aged 37 weeks, the highest amount of testosterone was found in group 4 (615.00 pg/ $\mathrm{ml})$ and the lowest in group $0(188.50 \mathrm{pg} / \mathrm{ml})$, which indicates the same trend as in young (20-week-old) roosters. 
Table 2. Effect of isoflavones on the body weight and testicular weight of the roosters

\begin{tabular}{|c|c|c|c|c|c|}
\hline \multirow{4}{*}{ Measured parameters } & \multicolumn{5}{|c|}{ Group } \\
\hline & 0 & 1 & 2 & 3 & 4 \\
\hline & \multicolumn{5}{|c|}{ content of added soybean isoflavones in the feed $(\mathrm{mg} / \mathrm{kg})$} \\
\hline & - & 300 & 600 & 1200 & 1800 \\
\hline Average body weight (g) & $1847 \pm 316$ & $1648 \pm 394$ & $1917 \pm 548$ & $1880 \pm 251$ & $1765 \pm 104$ \\
\hline average body weight (g) & $1847 \mathrm{a}$ & & & $5 \mathrm{~b}$ & \\
\hline \multicolumn{6}{|l|}{ Average weight of testicle (g) } \\
\hline left $(\mathrm{g})$ & 6.59 & 5.27 & 6.72 & 6.90 & 5.33 \\
\hline right $(\mathrm{g})$ & 6.40 & 4.99 & 5.72 & 6.62 & 5.01 \\
\hline left + right $(g)$ & 12.99 & 10.26 & 12.44 & 13.52 & 10.34 \\
\hline \multicolumn{6}{|c|}{ Relative weight of testicle ( $\%$ of live weight) } \\
\hline left $(\%)$ & 0.36 & 0.32 & 0.35 & 0.37 & 0.30 \\
\hline right $(\%)$ & 0.35 & 0.30 & 0.30 & 0.35 & 0.28 \\
\hline left + right $(\%)$ & 0.70 & 0.62 & 0.65 & 0.72 & 0.58 \\
\hline
\end{tabular}

$\mathrm{a}, \mathrm{b}$ - values in the same row with no common superscript differ significantly $(\mathrm{P}<0.05)$.

Table 3. Effect of isoflavones on serum testosterone concentration in the roosters $(\mathrm{pg} / \mathrm{ml})$

\begin{tabular}{|c|c|c|c|c|c|c|}
\hline & \multicolumn{5}{|c|}{ Group } & \multirow{2}{*}{ Average } \\
\hline & 0 & 1 & 2 & 3 & 4 & \\
\hline \multicolumn{7}{|l|}{ Start of the experiment: } \\
\hline rooster age in weeks & 20 & 20 & 20 & 20 & 20 & 20 \\
\hline testosterone $(\mathrm{pg} / \mathrm{ml})$ & 567.00 & 1298.33 & 736.50 & 1083.00 & 788.67 & $894.70 \mathrm{~A}$ \\
\hline percentage & 100 & 100 & 100 & 100 & 100 & 100 \\
\hline \multicolumn{7}{|l|}{ End of the experiment: } \\
\hline rooster age in weeks & 37 & 37 & 37 & 37 & 37 & 37 \\
\hline testosterone $(\mathrm{pg} / \mathrm{ml})$ & 188.50 & 268.50 & 223.00 & 238.33 & 615.00 & $306.67 \mathrm{~B}$ \\
\hline percentage & 33.24 & 20.68 & 30.28 & 22.01 & 77.98 & 34.28 \\
\hline
\end{tabular}

A, B - values in the same column with no common superscript differ significantly $(\mathrm{P}<0.01)$.

The average concentration of testosterone in the blood of roosters aged 20 weeks was $894.70 \mathrm{pg} / \mathrm{ml}$, which is nearly 3 times as much as in the blood of roosters aged 37 weeks $(306.67 \mathrm{pg} / \mathrm{ml})$. The average concentration of testosterone in the blood of 37 -week-old roosters, expressed as a relative number in comparison with young (20week-old) roosters was $34.28 \%$.

\section{Discussion}

The effects of isoflavones (genistein and daidzein) on the growth performance of animals and birds have been variable (Greiner et al., 2001 a, b; Payne et al., 2001; 
Wilhelms et al., 2006). According to our study, the average body weight of birds from isoflavone-supplemented groups was $2.82 \%$ lower compared with group 0 $(\mathrm{P}<0.05)$. This finding is in contrast with the experiment with male broilers in which the weight gain of birds significantly increased after supplementation of 10 and $20 \mathrm{mg}$ isoflavones $/ \mathrm{kg}$ (Jiang et al., 2007). The results suggest that the effect of isoflavones (daidzein and genistein) on the body weight may be related to the duration of the treatment and the amount of supplemented isoflavones in the feed.

The relative weight of measured testicles showed that in group 4 their weight was the lowest in relation to body weight. The highest relative weight was found in the control group and in group $3(0.70 \%$ and $0.72 \%$, respectively). These results suggest that isoflavones could influence the decline in testicular weight.

The serum testosterone concentration was significantly higher in 20 -week-old roosters in comparison with roosters aged 37 weeks $(\mathrm{P}<0.01)$. Fluctuations in the average values of the testosterone content were noticed in the groups of different age and in the treated groups. The testosterone concentration was higher in treated groups of 20-week-old roosters after 5 days of treatment (period of accommodation). This result indicates a rapid effect of isoflavones on testosterone concentration in young roosters. In the birds aged 37 weeks, testosterone concentration in the treated groups was also higher in comparison with the control group. The differences could be influenced by the feed treatment. Differences between experimental groups may be influenced by other factors such as individual social status, living space of inferior animals, and others. Further investigations are required to establish the initial time needed for isoflavone effect on testosterone concentration in blood and other factors. It is interesting to note that the blood concentration of testosterone in the roosters was $65.72 \%$ lower when they were 37 weeks compared to 20 weeks old.

The concentration of testosterone in the blood of young (20-week-old) roosters is similar to that found in 18-week-old roosters according to Gryzińska et al. (2011).

As shown by the investigations of several authors (Wilhelms et al., 2006; Akinola et al., 2007) soybean phytoestrogens influenced the development of androgenic organs and hormonal status of chickens during the growth period (adolescent period) and in young males. In our study, no significant effect was found in the roosters kept in cages.

In conclusion, our results suggested that isoflavones (genistein and daidzein) did not influence the testicular weight of ISA Brown roosters. The testosterone concentration in the blood serum was significantly higher in roosters aged 20 weeks in comparison with roosters aged 37 weeks $(\mathrm{P}<0.01)$. Further experiments are required to investigate the influence of isoflavones on some other androgenic characteristics of ISA Brown roosters.

\section{References}

A kinola O.B., Akinlolu A.A., A dekeye N.A., Oladosu O.S., Dosumu O.O., Olatun j i L.A. (2007). Effect of methanol extract of soy on testicular morphometry and plasma testosterone levels. Pak. J. Pathol., 18: 20-24. 
Akiyama T., Ishida J., Nakagawa S., Ogawara H., Watanabe S., Itoch N., Shibu y a M., F u k a m i Y. (1987). Genistein, a specific inhibitor of tyrosine-specific protein kinases. J. Biol. Chem., 262: 5592-5595.

Ci ereszko R., O pałka M., Kamińska B., Wojtczak M., Okrasa S., Dusza L. (2001). Luteotrophic action of prolactin during the early luteal phase in pigs: the involvement of protein kinases and phosphatases. Reprod. Biol., 1: 63-83.

C i e r e s zk o R., O pałk a M., K a m iń s ka B., Gór s k a T., D u s z a L. (2003). Prolactin signaling in porcine theca cells: the involvement of protein kinases and phosphatases. Reprod. Fert. Develop., 15: $27-35$.

G r e in e r L.L., S t a h ly T.S., S t a b e 1 T.J. (2001 a). The effect of dietary soy daidzein on pig growth and viral replication during a viral challenge. J. Anim. Sci., 79: 3113-3119.

Gr e in e r L.L., S t a h ly T.S., S t a b e 1 T.J. (2001 b). The effect of dietary soy genistein on pig growth and viral replication during a viral challenge. J. Anim. Sci., 79: 1272-1279.

Gryzińska M., Strachecka A., Krauze M. (2011). Concentration of testosterone in blood serum in roosters of the Polbar breed depending on age. Ann. UMCS, XXIX (4): 46-50.

Ji ang Z.Y., Ji ang S.Q., Lin Y.C., X i P.B., Yu D.Q., W u T.X. (2007). Effects of soybean isoflavone on growth performance, meat quality, and antioxidation in male broilers. Poultry Sci., 86: 1356-1362.

K a mińska B., C i e reszko R.E., O pałka M., D u s za L. (2002). Prolactin signaling in porcine adrenocortical cells: involvement of protein kinases. Domest. Anim. Endocrin., 23: 475-491.

K u r z e r M.S., X u X. (1997). Dietary phytoestrogens. Annu. Rev. Nutr., 17: 353-381.

L e op old A.S., Erw in M., Oh J., B rowning B. (1976). Phytoestrogens: adverse effects on reproduction in California quail. Science, 191: 98-100.

Makarevich A., Sirotkin A., Taradajnik T., Chrenek P. (1997). Effects of genistein and lavendustin on reproductive processes in domestic animal in vitro. J. Steroid Biochem. Mol. Biol., 63: 329-337.

Mes i a o S., Katz S.L., L e e J.Y., J a ffe R.B. (1999). Phytoestrogens alter adrenocortical function: Genistein and daidzein suppress glucocorticoid and stimulate androgen production by cultured adrenal cortical cells. J. Clin. Endocr. Metab., 84: 2443-2448.

Murkies A.L., Wilcox G., Davis S.R. (1998). Phytoestrogens. J. Clin. Endocr. Metab., 83: 297-303.

Payne R.L., B idner T.D., S o u the rn L.I., Gea ghan J.P. (2001). Effects of dietary soy isoflavones on growth, carcass traits and meat quality in growing-finishing pigs. J. Anim. Sci., 79: 1230-1239.

S n e d e c or W.G., C o c hr a n G.W. (1989). Statistical Methods. 8th ed., Iowa State University Press, USA.

Whitehead S.A., L a c y M. (2000). Protein tyrosine kinase activity of lavendustin A and the phytoestrogen genistein on progesterone synthesis in cultured rat ovarian cells. Fertil. Steril., 73: 613-619.

W i 1 h e $1 \mathrm{~m}$ s K.W., S c a n e s C.G., A n d e r s o n L.L. (2006). Lack of estrogenic or antiestrogenic actions of soy isoflavones in an avian model: The Japanese quail. Poultry Sci., 85: 1885-1889.

Accepted for printing 8 X 2012

\section{NATASHA GJORGOVSKA, KIRIL FILEV}

\section{Wpływ izoflawonów na masę jąder oraz wydzielanie testosteronu u kogutów ISA Brown}

\section{STRESZCZENIE}

Izoflawony to fitoestrogeny, które powodują działania estrogenopodobne u zwierząt oraz ludzi. $\mathrm{Z}$ powodu ich charakterystycznego działania, celem naszego eksperymentu było zbadanie wpływu genisteiny oraz daidzeiny na wagę jąder i wydzielanie testosteronu u kogutów ISA Brown. 
Genisteina oraz daidzeina będące niesterydowymi fitoestrogenami zostały dodane w dużej ilości do paszy dla kogutów, natomiast izoflawony sojowe zostały dodane w ilościach 0, 300, 600, 1200 oraz $1800 \mathrm{mg} / \mathrm{kg}$ paszy.

Pod koniec 37. tygodnia nie stwierdzono istotnej różnicy wśród grup w odniesieniu do wagi jąder $(\mathrm{P}>0,05)$ i wydzielania testosteronu $(\mathrm{P}>0,05) \mathrm{w}$ badanej krwi zwierząt. Stężenie testosteronu we krwi młodszych kogutów (20-tygodniowych) było znacząco większe niż u kogutów 37-tygodniowych $(\mathrm{P}<0,01)$. Genisteina i daidzeina obecne w paszy kogutów nie wpływają na wagę jąder kogutów, przy czym istotne różnice nie zostały stwierdzone. Wymagane jest prowadzenie dalszych doświadczeń w celu zbadania wpływu izoflawonów na inne androgenne właściwości u kogutów. 